\title{
Laboratory and Field Studies Demonstrating the Insecticidal Potential of Diatomaceous Earth against Wheat Aphids in Rice-wheat Cropping System of Punjab (India)
}

\author{
B. $\mathrm{SINGH}^{1 *}$ and V. SINGH ${ }^{2}$ \\ ${ }^{1}$ Department of Plant Breeding and Genetics, \\ ${ }^{2}$ Department of Soils, Punjab Agricultural University, Ludhiana-141004, India
}

(Received 26 October 2015; Accepted 26 January 2016)

\begin{abstract}
Aphids have acquired the status of major pest in North-western plains of India. A complex of five species infests the wheat in this part of the country. The diatomaceous earth (DE) has the potential to substitute the most widely used method of chemical control. Laboratory and field investigations were conducted to evaluate the effectiveness of DE either as soil or foliar application for suppression of wheat aphids during 2013-2014 and 2014-2015. The fecundity, adult longevity and total developmental duration of Rhopalosiphum padi decreased with the increasing dosage of soil application of DE in laboratory evaluation. However in field studies, no significant difference in aphid population was observed among different levels of DE application in soil. Foliar application of DE $150 \mathrm{~kg} / \mathrm{ha}$ and higher dosages significantly reduced aphid population for initial two days but thereafter it had no effect on aphid prevalence. Wheat plant dusted with different dosages of DE did not show any visible injury but the reduction in chlorophyll content was observed in them. Overall, poor field efficacy coupled with loss of chlorophyll and safety issues relating to foliar application of DE proved against its use for control of sucking insect pests.
\end{abstract}

Keywords: diatomaceous earth, wheat, aphid incidence, laboratory, field, Punjab

\section{Introduction}

Wheat is the principal winter cereal crop of India and it was grown over 31.34 million hectare with an annual production of 95.91 million tonnes of food grains (Anonymous, 2014). Insect pest attack is the major problem in wheat production and annual monetary loss of Rs 413.68 billion has been reported due to insect pests in wheat in India (Dhaliwal et al. 2010). A number of insect pests attack wheat crop throughout the season, out of which aphids has acquired the status of major pest in North-western plains of India. A complex of five species, i.e. Sitobion miscanthi, S. avenae, Rhopalosiphum padi, $R$. maidis and Schizaphis graminum infest wheat crop in this part of the country. The aphids are largely controlled by application of insecticides in India. The utilization of biological control agents like bacteria and insect pathogenic fungi represents a possible alternative. These biological control agents have the potential to substitute the most widely used 
method of chemical control (Moore et al. 2000). The same is also true for diatomaceous earth (DE). They are inert dusts, originating from the fossils of phytoplankton or diatoms (Korunic 1998). DE is an important source of silicon and it imparts resistance against different insect pest (Aleksander et al. 1994; Ebeling 1971; Korunic 1998; Golob 1997; Subramanyam and Roesli 2000; Nikpay 2006). It was first noticed in 1880 in the USA that road dust killed caterpillars of the cotton moth (Stelle 1880). Until the 1950s, clay dusts, sand or silica gels had been used more extensively than DE. In the early 1950s, DE was used against insect pests (Bartlett 1951). DEs are reported as grain protectant against major stored grain insect pest (Arnaud et al. 2005; Athanassiou et al. 2007; Vardeman et al. 2007; Wakil et al. 2010). However, they are not evaluated against field insect pest. Furthermore, in the context of insect pest resistance, resurgence and health issues, people are getting more conscious of the residual effectiveness of different pesticides and demand for environment friendly and safe methods of pest control in wheat. Thus, the current studies were conducted to evaluate the effectiveness of DE either mixed with soil or its foliar application against aphid in wheat.

\section{Materials and Methods}

\section{Experimental site, material and environmental conditions}

These studies were conducted at the Experimental area, Department of Plant Breeding and Genetics, Punjab Agricultural University (PAU), Ludhiana (30 $55^{\prime} \mathrm{N}$ and $75^{\circ} 54^{\prime} \mathrm{E}$, $247 \mathrm{~m}$ above the sea level) during 2013-2014 and 2014-2015. The wheat variety PBW 621 was used in this study and its seeds were obtained from the Wheat Breeding Laboratory, Department of Plant Breeding and Genetics, PAU Ludhiana. The DE formulation used in the trial was aquatic algae prepared by Agripower silica Inc. It contains fossilized remains of either salt or freshwater diatoms and composed of silicon in the form of amorphous silica $\left(\mathrm{SiO}_{2}\right)$. The median particle diameter of DE is 2.6 microns.

Laboratory investigations were carried out in screen houses $(363 \times 109 \times 180 \mathrm{~cm})$ fitted with 30 mesh galvanized wire gauze. The split cages (Severin 1931) were used to confine aphids in potted wheat plants to study the effect of DE on different biological attributes of one of wheat aphid species, $R$. padi. The pots of size 20 and $25 \mathrm{~cm}$ diameter were used for raising the test plants and also for studying the effects of DE on few biological attributes of $R$. padi on wheat crop. A small hole was made at the bottom of pots to drain excess irrigation water. For raising insect culture, 4-5 seeds of wheat variety PBW 621 were sown at weekly intervals in earthen pots (made of clay) having well tilled soil. About one week after germination, these were thinned out to five tillers per pot. These pots were watered regularly and fertilizers were applied as per recommendations of Package of Practices of Punjab Agricultural University (PAU) to keep the plants healthy (Anonymous 2013). A colony of a $R$. padi was developed from a single aphid collected from a wheat field in the Experimental area, Department of Plant Breeding and Genetics, Punjab Agricultural University, Ludhiana. These insect were reared artificially in screen house conditions and next generation nymphs/aphids were used for experimentation. 

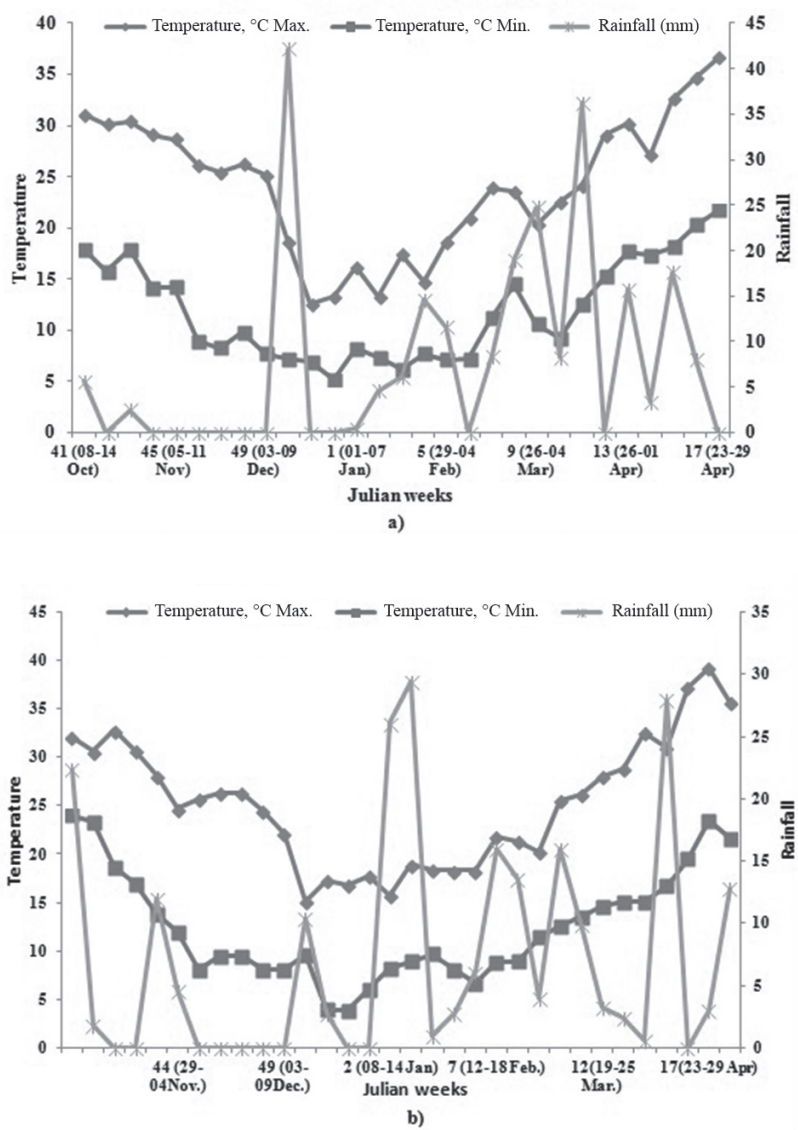

Figure 1. Temperature and rainfall during wheat growing season in a) 2013-2014 and b) 2014-2015

The region has a sub-tropical climate with cool and dry winters. The weather conditions did not differ substantially during the two years of study. The total rainfall was 229 mm during 2013-2014 and 229.10 mm during 2014-2015. Maximum and minimum temperature ranged from 12 to $31^{\circ} \mathrm{C}$ and 5 to $18{ }^{\circ} \mathrm{C}$, respectively, during the course of investigations (Fig. 1a and b).

\section{Experimental design and sampling methods for laboratory studies}

The effects of soil application DE on biological attributes of wheat aphids were compared at six different dosages in a laboratory experiment using Completely Randomized Design (CRD). The different treatments used in this study were DE0 $=($ No DE), DE $75=75 \mathrm{~kg} /$ ha of DE, DE150 = $150 \mathrm{~kg} / \mathrm{ha}$ of DE, DE300 $=300 \mathrm{~kg} / \mathrm{ha}$ of DE, DE450 $=450 \mathrm{~kg} / \mathrm{ha}$ of 
DE and DE600 = $600 \mathrm{~kg} / \mathrm{ha}$ of DE. Nitrogen (N) $120 \mathrm{~kg} / \mathrm{ha}$ and phosphorous (P) $60 \mathrm{~kg} /$ ha were uniformly applied in all the treatments.

Each pot was filled with $1.5 \mathrm{~kg}$ of moist soil and whole of $\mathrm{P}$ and DE was added at the time of sowing while half dose of $\mathrm{N}$ was applied at the time of sowing and second half was applied 21 days after sowing. Five pots having uniform size seedlings were kept for each treatment. These five pots served as five replications for each treatment. In all there were 30 pots and each pot was thinned to five tillers/pot. On ten days old plant, the seedlings in each pot were infested with a pair adult aphids having uniform weight. Infestation was done by placing the aphids in the whorls of the seedlings, using a small paintbrush. Thereafter all pots were split caged to prevent movement of aphids from one pot to another and escape and parasitism. After $48 \mathrm{~h}$, the adults were removed from each potted plant.

The observations were made on different biological parameters of $R$. padi, viz. nymphal duration, adult longevity, fecundity, total developmental duration and dry weight per plant (g) of wheat. Three observations were randomly recorded from each replication. For destructive measurements, such as dry weights, all plants inhibiting similar positions in each replication were uprooted and their roots were washed to remove soil associated with roots.

\section{Experimental design and sampling methods for field studies}

The crop was sown in the first week of November during 2013-2014 by following recommended standard package of practices of PAU (Anonymous 2013). The experiment was configured in Randomized Complete Block Design (RCBD) with four treatments replicated thrice. The row to row spacing was kept $22.5 \mathrm{~cm}$ in plots of $20 \times 15 \mathrm{~m}$. The four treatments used in field studies were same as used in laboratory studies except that DE75 and DE450 were not part of this experiment. The aphid incidence was recorded from five randomly selected tillers at flag leaf and milky grain stages. The selected shoots were kept uncovered to allow free migrations of aphids. During 2014-2015, another field experiment was conducted to ascertain the effect of foliar application of DE dust on aphid incidence. The experiment was designed in RCBD and treatments were kept same as in case of laboratory experiment. The foliar application of DE dust was done in the month of March at peak period of aphid incidence. The fine particles of DE were dusted by a plastic duster, which delivered the particles uniformly over foliage of wheat. Observation of aphid counts were recorded on five randomly selected shoots from each treatment. Predusting aphid counts were taken one day prior to application and post-dusting counts were made 1, 2, 7 and 15 days after DE application. Only live aphids were taken into account for counting the aphid population after application of treatments. The loss/gain of chlorophyll from leaves was calculated by SPAD meter (SPAD 502 Plus, Konica Minolta Inc.) and chlorophyll meter (CCM-200, Opti-Science Inc., Hudson, USA), respectively, during 2013-2014 and 2014-2015. Five readings were taken from the middle part of topmost leaves from each treatment. The readings were recorded at flag leaf stage during 2013-2014 whereas in 2014-2015, the observation were made 1, 2, 7 and 15 days after 
DE dusting. The CCM index was calculated by modifying the formula of Deol et al. (1997) as under:

$$
\mathrm{CCM}=\frac{\mathrm{CCM} \text { reading in control (without dusting) }-\mathrm{CCM} \text { reading in treatment }}{\mathrm{CCM} \text { reading in control (without dusting) }}
$$

At maturity, grain yield was recorded on whole plot basis and converted in quintals per hectare $(\mathrm{q} / \mathrm{ha})$.

\section{Statistical analysis}

For laboratory experiment, effect of DE on the developmental time, reproduction period and adult longevity were analyzed with one-way ANOVA and Tukey's HSD $(p=0.05)$ test was used for post-hoc comparisons. For field experiment, an analysis of variance (ANOVA) for a randomized complete block design (RCBD) was utilized for data analysis and means were separated by using Tukey's post-hoc test at 5 per cent probability level (IRRI, 1992). To normalize the data of laboratory and field studies, square root transformations were performed prior to statistical analysis.

\section{Results}

\section{Laboratory studies}

The results achieved in the experiment on biological attributes of $R$. padi including nymphal period, adult longevity, fecundity, total developmental time and plant dry weight wheat are presented in Table 1. There was no difference in developmental time of nymphs

Table 1. Laboratory studies showing effect of DEs mixed with soil on biological parameters of aphid (R. padi) in wheat

\begin{tabular}{|l|c|c|c|c|c|}
\hline $\begin{array}{c}\text { Treatments } \\
\text { No. }\end{array}$ & Nymphal period & Fecundity & Adult longevity & $\begin{array}{c}\text { Total developmental } \\
\text { duration }\end{array}$ & $\begin{array}{c}\text { Dry wt. of 5 tiller } \\
\text { (gm) at maturity }\end{array}$ \\
\hline DE0 & $10.40 \pm 0.69^{\mathrm{a}}$ & $\begin{array}{c}31.20 \pm 1.64 \\
(5.67)^{\mathrm{a}}\end{array}$ & $\begin{array}{c}20.94 \pm 0.70 \\
(4.68)^{\mathrm{a}}\end{array}$ & $\begin{array}{c}31.34 \pm 0.87 \\
(5.68)^{\mathrm{a}}\end{array}$ & $\begin{array}{c}2.55 \\
(1.88)^{\mathrm{c}}\end{array}$ \\
\hline DE75 & $10.18 \pm 0.66^{\mathrm{a}}$ & $\begin{array}{c}29.60 \pm 2.70 \\
(5.52)^{\mathrm{ab}}\end{array}$ & $\begin{array}{c}20.14 \pm 0.34 \\
(4.59)^{\mathrm{ab}}\end{array}$ & $\begin{array}{c}30.32 \pm 0.82 \\
(5.59)^{\mathrm{ab}}\end{array}$ & $\begin{array}{c}2.83 \\
(1.95)^{\mathrm{bc}}\end{array}$ \\
\hline DE150 & $9.90 \pm 0.42^{\mathrm{a}}$ & $\begin{array}{c}28.80 \pm 1.64 \\
(5.45)^{\mathrm{ab}}\end{array}$ & $\begin{array}{c}19.82 \pm 0.45 \\
(4.56)^{\mathrm{ab}}\end{array}$ & $\begin{array}{c}29.72 \pm 0.59 \\
(5.54)^{\mathrm{ab}}\end{array}$ & $\begin{array}{c}2.89 \\
(1.97)^{\mathrm{b}}\end{array}$ \\
\hline DE300 & $9.84 \pm 0.54^{\mathrm{a}}$ & $\begin{array}{c}27.00 \pm 1.65 \\
(5.25)^{\mathrm{ab}}\end{array}$ & $\begin{array}{c}19.98 \pm 0.45 \\
(4.58)^{\mathrm{ab}}\end{array}$ & $\begin{array}{c}29.58 \pm 0.88 \\
(5.52)^{\mathrm{ab}}\end{array}$ & $\begin{array}{c}2.85 \\
(1.96)^{\mathrm{bc}}\end{array}$ \\
\hline DE450 & $9.60 \pm 0.73^{\mathrm{a}}$ & $\begin{array}{c}24.60 \pm 2.70 \\
(5.05)^{\mathrm{ab}}\end{array}$ & $\begin{array}{c}19.34 \pm 0.78 \\
(4.50)^{\mathrm{b}}\end{array}$ & $\begin{array}{c}29.18 \pm 0.85 \\
(5.49)^{\mathrm{b}}\end{array}$ & $\begin{array}{c}3.62 \\
(2.14)^{\mathrm{ab}}\end{array}$ \\
\hline DE600 & $9.53 \pm 0.79^{\mathrm{a}}$ & $\begin{array}{c}23.60 \pm 3.65 \\
(4.94)^{\mathrm{b}}\end{array}$ & $\begin{array}{c}19.26 \pm 1.11 \\
(4.49)^{\mathrm{b}}\end{array}$ & $\begin{array}{c}28.80 \pm 1.36 \\
(5.45)^{\mathrm{b}}\end{array}$ & $\begin{array}{c}3.73 \\
(2.17)^{\mathrm{a}}\end{array}$ \\
\hline
\end{tabular}

Mean \pm S.E. followed by same letter (s) within the column are not significantly different at $p \leq 0.05$ (Tukey's post-hoc test)

Figures within the parentheses are square root transformed means. DE = Diatomaceous earth; 0,75, 150, 300, 450 and 600 are the dosages in $\mathrm{kg} / \mathrm{ha}$. 
Table 2. Field evaluation showing effect of DEs mixed with soil on aphid prevalence in wheat

\begin{tabular}{|l|l|c|c|c|}
\hline \multicolumn{1}{|c|}{ Treatments No. } & Flag leaf sage & Milky grain stage & Yield (q/ha) & SPAD value \\
\hline DE0 & $12.96(3.73)^{\mathrm{a}}$ & $12.13(3.62)^{\mathrm{a}}$ & $54.5^{\mathrm{b}}$ & $45.9^{\mathrm{b}}$ \\
\hline DE150 & $12.53(3.67)^{\mathrm{a}}$ & $11.83(3.57)^{\mathrm{a}}$ & $59.0^{\mathrm{a}}$ & $48.7^{\mathrm{a}}$ \\
\hline DE300 & $11.43(3.52)^{\mathrm{a}}$ & $12.00(3.60)^{\mathrm{a}}$ & $52.7^{\mathrm{b}}$ & $44.4^{\mathrm{b}}$ \\
\hline DE600 & $11.13(3.48)^{\mathrm{a}}$ & $11.33(3.51)^{\mathrm{a}}$ & $53.7^{\mathrm{b}}$ & $42.4^{\mathrm{b}}$ \\
\hline
\end{tabular}

Mean \pm S.E. followed by same letter (s) within the column are not significantly different at $p \leq 0.05$ (Tukey's post-hoc test) Figures within the parentheses are square root transformed means. DE = Diatomaceous earth; $0,150,300$ and 600 are the dosages in $\mathrm{kg} / \mathrm{ha}$.

among different treatments tested. However, it went on decreasing with the increased soil application of DE. There were significant differences in adult longevity of $R$. padi feeding on the different treatments examined in this study $(F=3.93, \mathrm{df}=5,24, p=0.0095)$. The adult longevity was significantly lower in DE600 as compared to untreated control (20.94 days) while all other treatments were on a par with each other. The total developmental duration also differed significantly among different treatments $(F=4.70, \mathrm{df}=5,24$, $p=0.0039$ ). It was maximum in untreated control (31.34 days) and went on decreasing with the increase in soil application of DE. The total developmental duration was significantly lower in DE450 (29.18 days) and DE600 (28.80 days) as compared to untreated control. The fecundity was maximum in untreated control (31.20 \pm 1.64 nymphs/female) and it was on a par with all dosages of DE except DE600 (23.60 \pm 3.65$)$. Maximum dry weight of randomly selected five tillers among different treatments was also significant $(F=7.77, \mathrm{df}=5,24, p=0.00018)$. It was significantly lower in untreated control $(2.55$ $\mathrm{g} / 5$ tillers) and went on increasing with the increase in soil application of DE.

\section{Field studies}

The aphids did not appear in early growth stages of wheat crop among different treatments. The first incidence of aphids was recorded 75-80 days after germination in the first fortnight of February. The data presented in Table 2 revealed that aphid population did not differ significantly among different treatments at flag leaf and milky grain stage during 2013-2014. The grain yield was significantly higher in soil application of DE150 (59.0 q/ ha) as compared to all other treatments which could be due high chlorophyll content (48.7 SPAD reading) recorded in this treatment.

In 2014-2015, DE was applied as foliar dust at peak period of aphid incidence. There was no difference in aphid incidence among different treatment plot before the application of DE (Table 3). One day after application, significantly lower aphids/tiller were recorded in all treatments as compared to untreated control (25.80). Minimum aphids/tiller (15) were observed in diatomaceous application $\sim 450 \mathrm{~kg} / \mathrm{ha}$ and it was on a par with all other treatments. A similar trend was observed two days after application of DE. However, after seven days of DE application, there was no difference in aphid population among different treatments. The application of DE dust also resulted in loss of chloro- 
Table 3. Effect of foliar application of DEs on aphid prevalence in wheat

\begin{tabular}{|l|c|c|c|c|c|c|}
\hline \multirow{2}{*}{$\begin{array}{c}\text { Treatments } \\
\text { No. }\end{array}$} & \multicolumn{5}{|c|}{ No. of aphids per shoot at different days after spraying (DAS) } & \multirow{2}{*}{ Yield (q/ha) } \\
\cline { 2 - 7 } & Pre-spray & 1 & 2 & 7 & 15 & \\
\hline DE0 & $22.40(4.82)^{\mathrm{a}}$ & $25.80(5.16)^{\mathrm{a}}$ & $23.80(4.97)^{\mathrm{a}}$ & $19.80(4.55)^{\mathrm{a}}$ & $18.60(4.42)^{\mathrm{a}}$ & $52.97^{\mathrm{a}}$ \\
\hline DE75 & $22.00(4.78)^{\mathrm{a}}$ & $17.40(4.28)^{\mathrm{b}}$ & $19.80(4.55)^{\mathrm{b}}$ & $18.60(4.41)^{\mathrm{a}}$ & $17.80(4.33)^{\mathrm{a}}$ & $53.15^{\mathrm{a}}$ \\
\hline DE150 & $20.60(4.63)^{\mathrm{a}}$ & $16.00(4.11)^{\mathrm{b}}$ & $19.60(4.53)^{\mathrm{b}}$ & $17.60(4.30)^{\mathrm{a}}$ & $17.00(4.23)^{\mathrm{a}}$ & $53.60^{\mathrm{a}}$ \\
\hline DE300 & $21.80(4.76)^{\mathrm{a}}$ & $15.80(4.09)^{\mathrm{b}}$ & $19.40(4.51)^{\mathrm{b}}$ & $17.00(4.23)^{\mathrm{a}}$ & $15.80(4.09)^{\mathrm{a}}$ & $53.95^{\mathrm{a}}$ \\
\hline DE450 & $20.00(4.57)^{\mathrm{a}}$ & $15.00(3.99)^{\mathrm{b}}$ & $18.20(4.37)^{\mathrm{b}}$ & $17.40(4.28)^{\mathrm{a}}$ & $17.00(4.23)^{\mathrm{a}}$ & $54.13^{\mathrm{a}}$ \\
\hline DE600 & $20.20(4.59)^{\mathrm{a}}$ & $15.20(4.01)^{\mathrm{b}}$ & $17.60(4.30)^{\mathrm{b}}$ & $17.20(4.25)^{\mathrm{a}}$ & $16.60(4.18)^{\mathrm{a}}$ & $53.33^{\mathrm{a}}$ \\
\hline
\end{tabular}

Mean \pm S.E. followed by same letter (s) within the column are not significantly different at $p \leq 0.05$ (Tukey's post-hoc test) Figures within the parentheses are square root transformed means. DE = Diatomaceous earth; 0, 75, 150, 300, 450 and 600 are the dosages in $\mathrm{kg} / \mathrm{ha}$.

phyll content (CCM index) from leaves. Significant differences in CCM index were observed among different treatments (Fig. 2). One day after treatment CCM index was minimum in DE75 and went on increasing in successive dosages of DE dusting. Similar trend was observed 2 and 7 days after treatment but no difference in CCM index was observed in treated and untreated leaves at 15 days after treatment. The grain yield was minimum in untreated plots $(52.97 \mathrm{q} / \mathrm{ha})$ and it was on a par with application dust of diatomaceous dust at different dosages.

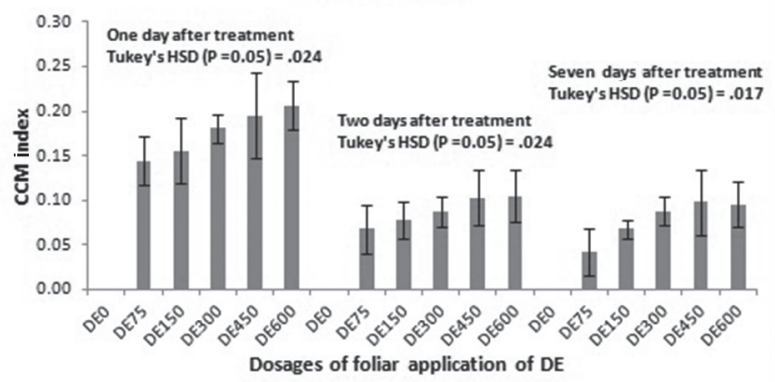

Figure 2. Loss of chlorophyll as measured by CCM index ( \pm standard deviation) in flag leaf of wheat by DE dusting 1,2 and 7 days after dusting

\section{Discussion}

Diatomaceous earth has been proved very effective for the control of stored grain insect (Kostyukovsky et al. 2010; Wakil and Schmitt 2015) and very few studies are available regarding their efficacy against soft body insects like aphids. Nakato (2010) observed that $\mathrm{DE} \sim 40 \mathrm{~g} / \mathrm{m}^{2}$ as dust was very effective in reducing cowpea aphid. Our study is the first one regarding the efficacy of DE against wheat aphids in India.

The results of the current laboratory studies indicate that soil application of DE influenced the biological attributes of wheat aphid (R. padi). Within a month of soil applica- 
tion of DE (at seedling stage), fecundity, adult longevity and total developmental duration of aphids showed significant variations but the nymphal period remained unaffected. The fecundity was significantly reduced when DE was applied at $600 \mathrm{~kg} / \mathrm{ha}$. The adult longevity and total developmental duration of aphid was also significantly reduced with the application of DE at $600 \mathrm{~kg} / \mathrm{ha}$. Hence the laboratory studies indicated that soil application of DE resulted in affecting the biology of wheat aphids at seedling stages and thus could reduce aphid population in early growth stages.

The results of field studies during 2013-2014 revealed that soil application of DE did not control aphids at reproductive stages of wheat crop. It could be due to the reason that soil application of DE temporarily increased the host plant resistance in early stages of wheat crop and its effect did not persist at later plant growth stages. Moreover, a complex of more than eleven aphid species infest wheat crop in the field (Singh 1983) while in laboratory investigations, results were recorded from only one aphid species (R. padi). But the foliar application of DE proved effective for the control of wheat aphids for 2 days after its application during 2014-2015. It could be due to its repellent properties and abrasion forming properties of DE (White et al. 1966). High dosage of DE increases insect repellence (Bartlett 1951). DE adheres to the insect body and damages the protective waxy layer of the insect cuticle by sorption and to a lesser degree by abrasion. The result is loss of water from insect body resulting in death of insects (Ebeling 1971). Generally smaller insects having large surface area in relation to their body volume are more sensitive because they lose greater amount of water from their body. The present decline in aphid population after foliar application of DE could be ascribed to their smaller size and greater surface area.

The smaller duration of field efficacy of foliar application of DE could be due to the reason that sucking insects recover the water loss more easily and are more resistant than those that metabolized water from their food (Flanders 1941). Another reason for shorter efficacy could be migration of aphids from neighboring plants. Wheat plant dusted with different dosages of DE did not show any visible injury but they might have affected the opening and closing of stomata of leaves by blocking the stomatal aperture. The reduction in chlorophyll content was observed in present investigations and it is also reported by Elseewi et al. (1980) at higher dusting rate. The reduction in chlorophyll was attributed to the alkalinity caused by excessive soluble salts on leaf surfaces. However, the lower dosages $\left(1.25 \mathrm{gm}^{-2}\right)$ of fly ash dust is reported to increases the chlorophyll content by reducing chlorophyll digesting enzymes and increasing the foliar temperature (Kausar et al. 2015).

Overall, poor field efficacy coupled with health and safety issues relating to foliar application of DE might prove against its use for control of sucking insect pests.

\section{References}

Alexander, P., Kitchener, J.A., Briscoe, H.V.A. 1944. Inert dust insecticides: Part III. The effect of dusts on stored products pests other than Calandra granaria. Ann. Appl. Biol. 31:156-159.

Anonymous 2013. Package of practices for crops of Punjab. Rabi. Punjab Agricultural University. Ludhiana, India.

Anonymous 2014. Progress Report of All India Coordinated Wheat and Barley Improvement Project 2013-14. Project Director's Report. Sharma, I. (ed.), DWR, Karnal, India. 120 p. 
Arnaud, L., Huong, T.T.L., Yves, B., Eric, H. 2005. Efficacy of diatomaceous earth formulations admixed with grain against populations of Tribolium castaneum. J. Stored Prod. Res. 41:121-130.

Athanassiou, C.G., Kavallieratos, N.G., Meletsis, C.M. 2007. Insecticidal effect of three diatomaceous earth formulations, applied alone or in combination, against three stored-product beetle species on wheat and maize. J. Stored Prod. Res. 43:330-334.

Bartlett, B.R. 1951. The action of certain "inert" dust materials on parasitic Hymenoptera. J. Economic Entomol. 44:891-896.

Deol, G.S., Reese, J.C., Gill, B.S. 1997. A rapid, nondestructive technique for assessing chlorophyll loss from greenbug (Homoptera: Aphididae) feeding damage on sorghum leaves. J. Kansas Ent. Soc. 70:305-312.

Dhaliwal, G.S., Jindal, V., Dhawan, A.K. 2010. Insect pest problems and crop losses: changing trends. Indian J. Ecol. 37:1-7.

Ebeling, W. 1971. Sorptive dusts for pest control. Annu. Rev. Entomol. 16:123-158.

Elseewi, A.A., Straughan, I.R., Page, A.L. 1980. Sequential cropping of fly ash-amended soil: Effects on soil chemical properties and yield elemental composition of plants. Sci. Total Environ. 15:247-259

Flanders, S.F. 1941. Dust as an inhibiting factor in the reproduction of insects. J. Econ. Entomol. 34:470-472.

Golob, P. 1997. Current status and future perspectives for inert dusts for control of stored product insects. J. Stored Prod. Res. 33:69-79.

IRRI 1992. IRRISTAT version 92. Department of Statistics, Int. Rice Res. Institute. Los Banos, Philippines.

Kausar, S., Hussain, M.A., Khan, A.A. 2015. Foliar application of fly ash on wheat crop. Res. J. Environ. Toxic 9:268-273.

Korunic, Z. 1998. Review diatomaceous earths, a group of natural insecticides. J. Stored Prod. Res. 34:87-97.

Kostyukovsky, M., Trostanetsky, A., Menasherov, M., Yasinov, G., Hazan, T. 2010. Laboratory evaluation of diatomaceous earth against main stored product insects. In: Proc. $10^{\text {th }}$ Int. Working Conference on Stored Product Protection. June to 2 July 2010, Estoril, Portugal. Julius Kühn-Institut, Berlin, Germany. pp. 701705.

Moore, D., Lord, J.C., Smith, S.M. 2000. Pathogens. In: Subramanyam, B.H., Hagstrum, D.W. (eds), Alternatives to Pesticides in Stored-product IPM. Kluwer Academic Publishers. Dordreech, The Netherlands. pp. 193-227.

Nakato, G.V. 2010. Effects of diatomaceous earth on cowpea field pests in Uganda. M.Sc. Thesis. http://hdl. handle.net/10570/918

Nikpay, A. 2006. Diatomaceous earths as alternatives to chemical insecticides in stored grain. Insect Sci. 13:421-429.

Severin, H.H.P. 1931. Modes of antilops transmission by beet leaf beetle Eutettix tenellus (Baker). Hilgardia 6:254-256.

Singh, C. 1983. Modern Technology of Raising Field Crops. Oxford \& IBM Publishing Co. Delhi, India. pp. $126-139$.

Stelle, J.P. 1880. Road dust vs. cotton-worms. American Entomol. 3:251-252.

Subramanyam, B.H., Roesli, R. 2000. Inert dusts. In: Subramanyam, B.H., Hagstrum, D.W. (eds), Alternatives to Pesticides in Stored-Product IPM. Kluwer Academic Publishers. Dordreecht, The Netherlands. pp. 321-380.

Vardeman, E.A., Arthur, F.H., Nechols, J.R., Campbell, J.F. 2007. Efficacy of surface application with diatomaceous earth to control Rhyzopertha dominica (F.) (Coleoptera: Bostrichidae) in stored wheat. J. Stored Prod. Res. 43:335-341.

Wakil, W., Ashfaq, M., Ghazanfar, M.U., Riasat, T. 2010. Susceptibility of stored-product insects to enhanced diatomaceous earth. J. Stored Prod. Res. 46:248-249.

Wakil, W., Schmitt, T. 2015. Field trials on the efficacy of Beauveria bassiana, diatomaceous earth and Imidacloprid for the protection of wheat grains from four major stored grain insect pests. J. Stored Prod. Res. 64:160-167.

White, G.D., Berndt, W.L., Schesser, J.H., Fified, C.C. 1966. Evaluation of inert dusts for the protection of stored wheat in Kansas from insect attack. Agric. Res. Service. United States Department of Agriculture. ARS- 51-8. Washington, DC, USA. 21 p. 